\title{
Participatory Democracy as a Constitutional Requirement: Experiences with Citizen Participation in Post- Revolutionary Tunisia
}

\author{
Eva Diehl
}

\begin{abstract}
The Tunisian Constitution of 2014 requires local authorities to adopt mechanisms of participatory democracy. This paper presents how citizen participation in development planning has been implemented by the Tunisian administration in the frame of two Tunisian-German cooperation projects funded by the German Federal Ministry of Economic Cooperation and Development (BMZ) and implemented by the Deutsche Gesellschaft für Internationale Zusammenarbeit (GIZ) GmbH. ${ }^{1}$ The first project example consists of a multi-stakeholder dialogue for integrated water resource management in Kairouan, central Tunisia, whereas the second example is about citizen participation in planning small-scale investments in local infrastructure in different parts of the country. External facilitation, inclusiveness, transparency, expectation management and commitment from all levels of the administration are described as success factors for implementing participatory processes. Similar cooperation projects supporting citizen participation should be aware of on-going power struggles at different levels, as well as the challenges of local legal implementation. Both examples illustrate areas of tension between the remnants of the authoritarian past in Tunisia, and inno-
\end{abstract}

* Eva Diehl holds a Magistra artium (M.A.) degree in Social anthropology, English and Public Law from Freie Universität Berlin (Germany), and completed postgraduate studies in International Development Cooperation at the Center for Advanced Training in Rural Development (SLE) at Humboldt-Universität Berlin (Germany). She has worked in international cooperation with GIZ in Germany, Ethiopia and Tunisia since 2010. From 2015 to 2017, she worked as an advisor on water governance based in Kairouan, Tunisia, in the project described here in section C.I. From 2017 to mid-2020, she was the manager of the "Initiative for Regional Development" described in section C.II. The analysis and conclusions drawn in this article result entirely from the author's own judgement and do not represent official views of GIZ or the German government. For correspondence, please use e-diehl@web.de.

This paper is based on a presentation delivered on November 15, 2019 at the 46th African Law Association Annual Conference on "Judiciary, Public Administration and Rule of Law in Africa". The author would like to thank the conference organisers for the invitation, and the conference participants as well as her colleagues for critical remarks and valuable feedback.

1 GIZ is a service provider in the field of international cooperation for sustainable development and international education work. Its main commissioning party is the BMZ. Together with its partners in national governments worldwide and cooperation partners from the worlds of business, research and civil society, GIZ works flexibly to deliver effective solutions that offer people better prospects and sustainably improve their living condition. Cf. https://www.giz.de/en/aboutgiz/profile.html, accessed on 10 October 2020, for more details. 
vative democratic approaches. Furthermore, the examples allow to observe how ambiguities regarding the distribution of decision-making power between national, regional and local level become manifest in the on-going process of decentralisation in Tunisia.

\section{A. Introduction}

When the Tunisian Constituent Assembly adopted the new democratic Constitution of the Tunisian Republic on 26 January $2014,{ }^{2}$ it placed a strong focus on participation in Chapter VII on Local Government. Article 139 reads: "Local authorities shall adopt the mechanisms of participatory democracy and the principles of open governance to ensure the broadest participation of citizens and of civil society in the preparation of development programmes and land use planning, and follow up on their implementation, in conformity with the law."3

The present paper presents experiences with different forms of citizen participation observed between 2015 and 2019 during the implementation of two Tunisian-German cooperation projects funded by the German Federal Ministry for Economic Cooperation and Development (BMZ) and carried out by the Deutsche Gesellschaft für Internationale Zusammenarbeit (GIZ) GmbH. Both projects aim at supporting decentralised governance and enhancing citizen participation - one in the water sector, and the other through a cross-sectoral approach on regional development.

Following a brief introduction of the socio-political and legal contexts, the first case study focuses on water user participation in water governance through a multi-stakeholder platform called the "Water Forum" of Sbikha in Kairouan, central Tunisia. The second case study draws on experiences of involving citizen in decision-making about small-scale investments in social infrastructure, such as renovating and equipping school canteens and local health centres. Challenges that occurred in the process of implementing different citizen participation formats are analysed in order to then attempt drawing some general conclusions about citizen participation and local governance in current-day Tunisia. Hypotheses and questions for further research are pointed out, and success factors and important considerations for similar cooperation projects supporting citizen participation are highlighted.

2 Cf. Grote, Rainer, The New 2014 Tunisian Constitution, in: Oxford Constitutional Law, Oxford University Press 2020, https://oxcon.ouplaw.com/page/404, accessed on 18 October 2020.

3 International IDEA Institute for Democracy and Electoral Assistance, ConstitutionNet, The Constitution of the Tunisian Republic, Final Constitution of the Tunisian Republic adopted on 26 January 2014, unofficial translation prepared by UNDP and reviewed by International IDEA, http://constitut ionnet.org/sites/default/files/2014.01.26__final_constitution_english_idea_final.pdf, accessed on 17 May 2020. 


\section{B. Socio-political and legal contexts}

\section{Recent Tunisian political history}

The Republic of Tunisia is a state in the Maghreb region of North Africa, bordering with Algeria in the West and Southwest, Libya in the Southeast, and the Mediterranean Sea in the North and East. At 163,610 square kilometres, its territory is a little less than half the size of Germany (with 357,022 square kilometres), while neighbouring Algeria is the largest country in Africa, at 2,381,740 square kilometres - more than fourteen times the territorial size of Tunisia. ${ }^{4}$ In July 2019, the Tunisian National Statistical Institute estimated Tunisia's population at 11.72 million, of which an estimated $70 \%$ is urban, with 2.37 million living in Tunis alone. ${ }^{5}$

After independence from France in 1956, the Tunisian monarchy was abolished, and the Tunisian Republic was established in 1957. Its first elected president, Habib Bourguiba, ruled from 1959 to 1989, followed by president Zine el-Abidine Ben Ali, who was in power from 1989 to 2010. Despite the democratic ambitions and the modernist approach of the early Bourguiba regime, Tunisia developed more and more into a one-party autocratic state over time. ${ }^{6}$ Increasing socio-economic problems, rising inequality and an unemployment rate of more than $25 \%$ among educated youth led to protests in December 2010. After Mohammed Bouazizi, a young fruit seller without job prospects, set himself on fire outside a municipal office in the town of Sidi Bou Zid, local protests quickly developed into nationwide demonstrations, culminating in a revolt urging the ruling president to resign. Ben Ali fled the country on 14 January 2011. ${ }^{7}$ The "Jasmine Revolution" that forced Ben Ali out of power inspired a series of pro-democracy protests and uprisings in the region known as the "Arab Spring." In Tunisia, it resulted in a peaceful democratic transition.

4 Territorial sizes of all three countries taken from the CIA World Factbook as total size, including land and water. Central Intelligence Agency, World Factbook, Geography Tunisia: https://www.cia. gov/library/publications/the-world-factbook/geos/ts.html; ibid., Geography Germany: https:/www.c ia.gov/library/publications/the-world-factbook/geos/gm.html; ibid., Geography Algeria: https://ww w.cia.gov/library/publications/the-world-factbook/geos/ag.html, all accessed on 12 May 2020.

5 Institut National de la Statistique, Estimation de la population, Population au 1er Juillet: http://www .ins.tn/fr/themes/population, accessed on 12 May 2020; cf. also Central Intelligence Agency, World Factbook, People and Society Tunisia: https:/www.cia.gov/library/publications/the-world-factbook/ geos/ts.html, accessed on 12 May 2020.

6 Bundeszentrale für politische Bildung, Hintergrund Aktuell 18.3.2016, 60 Jahre tunesische Unabhängigkeit: https:/www.bpb.de/politik/hintergrund-aktuell/223304/1956-tunesien-unabhaengig, accessed on 12 May 2020.

7 Werenfels, Isabelle, Vorreiter Tunesien, https://www.bpb.de/internationales/afrika/arabischer-fruehli ng/52395/tunesien, accessed on 12 May 2020; Beaumont, Peter, Mohammed Bouazizi: the dutiful son whose death changed Tunisia's fate, https://www.theguardian.com/world/2011/jan/20/tunisian-f ruit-seller-mohammed-bouazizi, accessed on 17 May 2020.

8 Encyclopaedia Britannica, The Jasmine Revolution, Ouster of Zine al-Abidine Ben Ali: https://ww w.britannica.com/place/Tunisia/The-Jasmine-Revolution\#ref1129225, accessed on 17 May 2020. 
Tunisians voted on 23 October 2011 to determine the composition of the 217-member Constituent Assembly, ${ }^{9}$ and a process to build a new constitution was put in place. Tensions between the conservative and the secular political camps about the content of the Constitution led to another crisis towards the end of the process. A national dialogue process brought the conflicting parties back to the negotiating table and finally led to the adoption of what has often been praised as one of the most progressive and democratic constitutions in the history of the region. ${ }^{10}$ The National Dialogue Quartet that supported this dialogue process received the Nobel Peace Prize in 2015, "for its decisive contribution to the building of a pluralistic democracy in Tunisia." 11

\section{Geographic disparities}

The political opposition between the more conservative Islamic religious and the more secular parts of society that became manifest in the constitution-building process is not the only line of conflict in the country. Tunisia is characterised by great regional disparities, such that apart from political lines of conflict, there are also economic and geographic conflict lines. ${ }^{12}$ The Tunisian territory is divided into twenty-four governorates. ${ }^{13}$ The focus of public investments in the past has been on the coast, with the capital, Tunis, as well as larger cities like Sfax and Sousse as main economic centres and centres of the tourism industry. Tourism traditionally concentrated on the coastal areas, and more than $80 \%$ of the industrial zones are located at the coast. ${ }^{14}$ In contrast, the interior regions have historically been neglected, and indicators such as unemployment rates, illiteracy rates and statistics on ac-

9 Ibid.

10 Gallien, Max, in: PeaceLab, S2E3 Tunesien: Welche politischen und wirtschaftlichen Reformen sind notwendig?

https://peacelab.blog/2019/10/s2e3-tunesien-welche-politischen-und-wirtschaftlichen-reformen-sin d-notwendig, minute 6ff., accessed on 17 May 2020.

11 The Nobel Prize, National Dialogue Quartet Facts, https://www.nobelprize.org/prizes/peace/2015/t ndq/facts/, accessed on 17 May 2020. The National Dialogue Quartet consisted of four organizations: the Tunisian General Labour Union (UGTT), the Tunisian Confederation of Industry, Trade and Handicrafts (UTICA), the Tunisian Human Rights League (LTDH), and the Tunisian Order of Lawyers, cf. ibid.

12 Salehi, Mariam, in: PeaceLab, S2E3 Tunesien: Welche politischen und wirtschaftlichen Reformen sind notwendig? https://peacelab.blog/2019/10/s2e3-tunesien-welche-politischen-und-wirtschaftlic hen-reformen-sind-notwendig, minute 8ff., accessed on 17 May 2020.

13 Central Intelligence Agency, World Factbook, Government Tunisia: https://www.cia.gov/library/p ublications/the-world-factbook/geos/ts.html, accessed on 17 May 2020.

14 United Nations University UNU-Wider Research Brief, The effect of clustering in Tunisia, https:// www.wider.unu.edu/sites/default/files/11-The-effect-of-clustering-in-Tunisia.pdf, accessed on 17 May 2020. According to this source, "more than $83 \%$ of industrial firms are located on the country's coast, with nearly $40 \%$ of these located in either the Tunis governorate or the Sfax governorate where there are superior infrastructure and transportation networks more conducive to industry". 
cess to health services and higher education demonstrate the vast regional disparities, ${ }^{15}$ which remain a source of conflict and social unrest. Salehi points out that political participation, too, happened more in the coastal regions and the capital in the past, such that more and more grievances formed among the population in the central regions because of a lack of political participation on the one hand, and a lack of investment in infrastructure, education, and development of the central regions on the other hand - in spite of the fact that, as this population highlights, the country's true wealth is actually located in the centre of the country. ${ }^{16}$

The rise of civil society organisations in Tunisia after 2011 can be seen as an indicator of the population's strong demand to get more involved in state decision making and development planning. The number of civil society organisations in Tunisia rose from an estimated 9,000 before 2011 to around 19,000 in 2016, of which approximately 2,600 are considered to be active according to the civil society platform Jamaity. ${ }^{17}$

\section{Legislation on citizen participation}

The 2014 Constitution embodies decentralisation as a general principle in Article 14: "The state commits to strengthen decentralisation and to apply it throughout the country, within the framework of the unity of the state." 18 In Chapter VII on Local Government, Article 139 rules that "Local authorities shall adopt the mechanisms of participatory democracy and the principles of open governance to ensure the broadest participation of citizens and of civil society in the preparation of development programmes and land use planning, and follow up on their implementation, in conformity with the law." 19

15 For example, according to data from the National Institute of Statistics, in 2014 the illiteracy rate among the population aged over 10 was 32,6\% in Kasserine (41,5\% among women), p. $21 \mathrm{ff}$.

$35 \%$ in Kairouan, (44\% among women), p. $21 \mathrm{ff}$., and $32,9 \%$ in Jendouba ( $41,8 \%$ among women), p. $21 \mathrm{ff}$., compared to $19,3 \%$ national average ( $25,6 \%$ national average for women), $13,4 \%$ in Sousse (18,5\% among women), and $16,9 \%$ in Sfax (23,2\% among women), cf. Institut National de la Statistique (INS), Kasserine à travers le recensement général de la population et de l'habitat 2014, http://www.ins.tn/sites/default/files/17_kasserine_0.pdf, p. 21ff., INS, Kairouan à travers le recensement général de la population et de 1'habitat 2014, http://www.ins.tn/sites/default/files/1 6 kairouan_0.pdf, p. 21ff., INS, Jendouba à travers le recensement général de la population et de 1 'habitat 2014, http://www.ins.tn/sites/default/files/9 Jandouba.pdf, p. $21 \mathrm{ff} .$, INS, Sousse à travers le recensement général de la population et de l'habitat 2014, http://www.ins.tn/sites/default/files/1 2_sousse_0.pdf, p. 33ff., INS, Sfax à travers le recensement général de la population et de 1'habitat 2014, http://www.ins.tn/sites/default/files/15_sfax_0.pdf, p. 33ff., all accessed on 17 May 2020.

16 Salehi, Mariam, note 12, minute 10ff.

17 Salehi, Mariam/ Schäfer, Isabel: PÖK (Politökonomische Kurzanalyse) Tunesien, Hamburg: GIGA 2019, p. 15; cf. also Jamaity, La plateforme de la société civile tunisienne, https://jamaity.org, accessed on 10 April 2020.

18 International IDEA, note 3.

19 International IDEA, note 3. Cf. Constitution de la République Tunisienne, Article 14 : « L'État s'engage à renforcer la décentralisation et à la mettre en œuvre sur l'ensemble du territoire natio- 
At the end of April of 2018, after more than three years of legal development, the new 400 -article-long Tunisian Local Authorities Code was passed, ${ }^{20}$ regulating the roles and responsibilities of the Tunisian municipalities and regions in relation to the central state and defining the administrative division with respect to the municipalities. Now there are 350 municipalities within the 24 governorates. Some of these municipalities already existed before 2018 , but many were either newly created by the Code, or changed size as a result of the Code, both in terms of administrative territory and population. Following the municipal elections on 6 May 2018, Municipal Councils consisting of elected local representatives were formed for the first time.

In consistency with the constitutional provision, the Local Authorities Code specifies in Article 29 that, "It is mandatory that development and land use planning programmes be drafted in accordance with participatory democracy. The Local Community Council shall guarantee the effective participation of all inhabitants and civil society throughout the various stages of drafting such development and land use planning programs, as well as during their implementation and evaluation (...)." ${ }^{21}$ Currently, this participation certainly takes different forms in different municipalities and may be more or less operational and effective depending on local capacities and constellations. In regional capitals such as Béja or Sousse, banners of the Municipal Councils can be seen at the entry of the city hall and throughout the city, inviting citizens to participate in the Municipal Council debates.

\section{Strengthening participatory democracy: Two examples from Tunisian-German cooperation}

After the 2011 revolution, Tunisia saw a considerable rise in funds from European cooperation partners who wanted to support the consolidation of the young democracy. Like other European governments, the German government wants to contribute to stabilising the North African region in Europe's immediate neighbourhood, and actively supports the democratic

nal, dans le cadre de l'unité de l'État. »; Article 139 : « Les collectivités locales adoptent les mécanismes de la démocratie participative et les principes de la gouvernance ouverte, afin de garantir une plus large participation des citoyens et de la société civile à l'élaboration des projets de développement et d'aménagement du territoire et le suivi de leur exécution, conformément à la loi. », http://www.legislation.tn/sites/default/files/news/constitution-b-a-t.pdf, accessed on 17 May 2020.

20 Webmanagercenter, Code des Collectivités Locales: Chronologie, https://www.webmanagercenter. com/2018/05/06/419520/code-des-collectivites-locales-chronologie/, accessed on 17 May 2020.

21 Section 5 - De la démocratie participative et de la gouvernance ouverte, Art. 29 : « Les programmes de développement et d'aménagement du territoire sont obligatoirement élaborés en observant les procédés de la démocratie participative. Le conseil de la collectivité locale garantit une participation effective de tous les habitants et de la société civile au cours des différentes étapes d'élaboration des programmes de développement et d'aménagement du territoire et lors du suivi de leur exécution et de leur évaluation. (...) » Loi organique $\mathrm{n}^{\circ}$ 2018-29 du 9 mai 2018, relative au code des collectivités locales, http://www.collectiviteslocales.gov.tn/fr/code-des-collectivites-local es/, accessed on 17 May 2020. Translation to English by the author. 
and economic transition in Tunisia. ${ }^{22}$ Since the revolution, German cooperation with Tunisia concentrates on administrative reform and decentralisation, sustainable economic development, water, and renewable energy. ${ }^{23}$ Projects funded by BMZ and implemented by GIZ include projects explicitly dedicated to accompanying the decentralisation process and strengthening local and regional governance, but also projects supporting participatory democracy and regional governance in specific sectors, such as water and natural resource management. In view of the regional disparities described above, and with the intention of creating better prospects for the population in the structurally weak parts of the country, the focal areas of German cooperation have been mainly the interior regions, in particular the governorates of Béja, Siliana, Jendouba, and Kef in the North-West, and the governorates of Kairouan, Sidi Bou Zid, and Kasserine in the central West. The following example describes and analyses efforts of strengthening citizen participation in integrated water resource management in Kairouan, in central Tunisia.

\section{Example 1: Citizen participation in integrated water resource governance in central Tunisia}

1. The water situation in Kairouan

Tunisia is an extremely water scarce country, with agriculture being responsible for over $80 \%$ of the total water consumption. According to 2017 FAO data, Tunisia has $364 \mathrm{~m}^{3}$ of annual internal renewable water resources per inhabitant at its disposal, thereby classifying as a country belonging to the $9 \%$ of countries worldwide with absolute water scarcity. ${ }^{24}$ Kairouan is part of the hot, dry central Tunisian plain with a steppe climate, which is semiarid in the Northern part of the governorate and arid in the South. There is on average 250 $400 \mathrm{~mm}$ of rainfall per year, with generally hot, dry summers and humid winters. Rainfall is very irregular and varies greatly from one year to the next. ${ }^{25}$

22 Deutsche Botschaft Tunis, Deutsche Entwicklungszusammenarbeit mit Tunesien, https://tunis.dipl o.de/tn-de/themen/-/2302496, and Bundesministerium für wirtschaftliche Zusammenarbeit und Entwicklung, Tunesien -Land im Umbruch, https://www.bmz.de/de/laender_regionen/naher_osten _nordafrika/tunesien/index.jsp, both accessed on 17 May 2020.

23 Ibid.

24 United Nations, UN Water, "Water Scarcity", https://www.unwater.org/water-facts/scarcity/, accessed on 11 November 2019; FAO "Water Scarcity", http://www.fao.org/land-water/water/wate r-scarcity/en/, accessed on 24 May 2020; FAO 2016 AQUASTAT Main Database, Food and Agriculture Organization of the United Nations (FAO), http://www.fao.org/nr/water/aquastat/data/quer y/index.html?lang=en, "Tunisia : Total internal renewable water resources per capita $\left(\mathrm{m}^{3} / \mathrm{inhab} /\right.$ year)", accessed on 24 May 2020, the latest available data being from 2017. "Total renewable water resources per capita ( $\left.\mathrm{m}^{3} / \mathrm{inhab} / \mathrm{year}\right)$ " in Tunisia amount to $400 \mathrm{~m}^{3}$ in 2017 , according to the same database.

25 Office de Développement du Centre Ouest, Carrefour de la nature et de l'histoire, http://www.odco .nat.tn/upload/pdf/BrochureKairouan.pdf, accessed on 17 May 2020, p. 8. 
Kairouan is, at the same time, part of the agricultural centre of Tunisia and has groundwater and surface water resources at its disposal that are important for the central and coastal regions. According to the Development Office of the Central West, which is a substructure of the former Ministry for Regional Development and then became a part of the Ministry for Investment, Development and International Cooperation (MDICI), ${ }^{26}$ the annually available water resources in Kairouan are estimated at 312 million $\mathrm{m}^{3}$, of which 168 million $\mathrm{m}^{3}$ are mobilized by the three great dams of Sidi Saad, El-Houareb, and Nebhana, and the rest from groundwater resources. ${ }^{27}$ The governorate is strongly characterised by agricultural livelihoods, with few alternative sources of income for people in the rural areas. It provides more than $10 \%$ of the national agricultural produce, and agriculture provides a stable income for $70 \%$ of the population. ${ }^{28}$ The majority of the farmers have smallholdings of a size between 2 and 10 hectares; only few farmers have fields more than 100 hectares large. Main crops are olives and apricots, chillies, tomatoes, potatoes, beans, peas, and melons, all mainly as irrigated agriculture. The governorate of Kairouan is the primary producer of chillies and apricots in Tunisia, and its second-largest producer of olive oil. ${ }^{29}$

The groundwater resources in the governorate of Kairouan are rapidly being depleted, with the groundwater level decreasing for around two meters on average per year according to the data that were available in 2014 when the cooperation project on water resource governance described below was planned. ${ }^{30}$ At the same time, the region saw an exponential increase in illegitimate boreholes after the 2011 revolution; in 2017, the Tunisian Ministry of Agriculture estimated the number of unauthorised boreholes in the governorate of Kairouan at 2,500. ${ }^{31}$ There were also reports of water counters being removed, as well as unauthorized extensions of water pipes being installed before the counters. Many of the Agricultural Development Groups ("groupements de développement agricole," GDA) re-

26 Since the recent government reorganisation of August/ September 2020, the MDICI does not exist as an independent ministry any more, but has been integrated into the Ministry of Economy, Finances and Investment Promotion. Cf. Le360 Afrique - Afp, Tunisie: Le parlement approuve le gouvernement de technocrates dirigé par Mechichi, https://afrique.le360.ma/tunisie/politique/2020/ 09/02/31718-tunisie-le-parlement-approuve-le-gouvernement-de-technocrates-dirige-par-mechichi -31718 , accessed on 10 October 2020.

27 Office de Développement du Centre Ouest, note 25, p. 10; Elloumi, Mohamed, La Gouvernance des eaux souterraines en Tunisie, IWMI Project Report No. 7, December 2016, http://gw-mena.iw mi.org/wp-content/uploads/sites/3/2017/04/Rep.7-Groundwater-governance-in-Tunisia_final_cove r.pdf, accessed on 18 May 2020, p. 112.

28 According to 2009 data, cf. Office de Développement du Centre Ouest, note 25, p. $20 \mathrm{ff}$.

29 Office de Développement du Centre Ouest, note 25, p. $20 \mathrm{ff}$.

30 Cf. Elloumi, Mohamed, note 27, p. 114. Data for the Sisseb aquifer show an average decrease of the water table by $2 \mathrm{~m}$ per year from 1996-2000. The same report assessed the over-exploitation of water resources in Kairouan at $145 \%$, cf. ibid. p. 115 .

31 République Tunisienne, Ministère de l'Agriculture, des Ressources Hydrauliques et de la Pêche, Bureau de Planification et des Equilibres Hydrauliques, Rapport national du secteur de l'eau, Année 2017, http://www.onagri.nat.tn/uploads/statistiques/PRINT-2019\%20Secteur-eau.pdf, p. 32, accessed on 18 May 2020. 
sponsible for managing the water resources at local level have debts because the users do not pay their water bills. ${ }^{32}$

\section{A dialogic approach to water management}

Water catchment areas do not correspond to administrative divisions: The catchment area of the Nebhana dam in Kairouan serves up to four governorates with water. Its water resources are not only important for the governorate of Kairouan, but the dam also provides water resources for the Sahel region at the coast, which comprises the governorates of Sousse, Monastir and Mahdia.

The overexploitation of water resources in central Tunisia, the increasing pressure on the resources in Kairouan as well as their importance for the economic survival of the rural population were factors that led to the choice of the Nebhana catchment area as a pilot region of the project "Support To Integrated Water Resources Management" funded by BMZ and implemented by GIZ in cooperation with the Tunisian Ministry of Agriculture, Water Resources and Fisheries from 2013 to $2016 .{ }^{33}$ More specifically, the project focused on the delegation of Sbikha in the Northeast of the governorate of Kairouan, where, apart from the Nebhana dam, three important groundwater aquifers are located: Ain Bou Mourra, Chougafia and Sisseb-El-Alam. ${ }^{34}$ The most important regional implementation partner was the Regional Agricultural Development Commissariat of Kairouan as sub-structure of the Ministry of Agriculture. ${ }^{35}$

In the starting phase of this water project, both local and regional authorities and the farmers as main water users had become aware, each in their own respective sphere, of a need for change: the water users by realising that their wells were running dry, and that they needed ever stronger pumps and deeper boreholes in order to access the remaining ground-

32 Elloumi, Mohamed, note 27, lists the different governance challenges on p. 115.

33 Deutsche Gesellschaft für Internationale Zusammenarbeit (GIZ) GmbH, Factsheet "Entwicklung ländlicher Regionen - Integriertes Wasserressourcenmanagement (IWRM)", Tunis, October 2015. Funding was extended for a second project phase from 2016 to 2020, adding a second pilot area in the governorate of Sidi Bou Zid, cf. GIZ, Managing water resources and raising awareness, https:// www.giz.de/en/worldwide/62164.html, accessed on 18 May 2020. A third phase is in preparation at the time of writing. Cf. also République Tunisienne, Ministère de l'Agriculture, des Ressources Hydrauliques et de la Pêche, Bureau de Planification et des Equilibres Hydrauliques, Rapport national du secteur de l'eau, Année 2017, http://www.onagri.nat.tn/uploads/statistiques/PRINT-2019 $\% 20$ Secteur-eau.pdf, p. 22f., accessed on 18 May 2020.

34 Elloumi, Mohamed, La Gouvernance des eaux souterraines en Tunisie, IWMI Project Report No. 7, December 2016, http://gw-mena.iwmi.org/wp-content/uploads/sites/3/2017/04/Rep.7-Groundwa ter-governance-in-Tunisia_final_cover.pdf, p. 112f., accessed on 18 May 2020; maps of the Regional Agricultural Development Commissariat of Kairouan that were made available to GIZ in the frame of the cooperation project.

35 The "Commissariat Régionale de Développement Agricole, CRDA" is the deconcentrated regional authority pertaining to the Tunisian Ministry of Agriculture, Water Resources and Fisheries, which is responsible for water resource management at national level. 
water, and the authorities by daily witnessing a governance problem that had grown out of their control, considering the sheer number of unauthorised boreholes. This was the motivation for trying a "dialogic approach" based on the principles of integrated water resource management as defined by the Global Water Partnership: "Integrated Water Resources Management (IWRM) is a process which promotes the coordinated development and management of water, land and related resources in order to maximise economic and social welfare in an equitable manner without compromising the sustainability of vital ecosystems and the environment." ${ }^{36}$ The idea was to create a multi-stakeholder platform engaging the local and regional administration, water user representatives, water and electricity companies, civil society organisations, and other stakeholders, in a dialogue about how to better manage the local water resources, finding mutually acceptable solutions that would respect social, economic, and environmental criteria according to IWRM principles. These mutually agreed upon solutions were to be documented in a joint charter and were to culminate in an action plan.

GIZ supported the creation of this multi-stakeholder platform, facilitating a dialogue process in several steps from 2015 to 2016 jointly with the Potsdam-based Collective Leadership Institute ${ }^{37}$ and a Tunisian sociologist as sub-contractors. The first stage of the dialogue was a preparation stage consisting of the identification of the dialogue participants and discussions within each separate group of participants. Based on a sociological study ${ }^{38}$ and focus group discussions with over 300 water users in the different localities of the water catchment area around Sbikha, mandated user representatives were identified. ${ }^{39}$ Then, discussions accompanied by dialogue training were held separately both within the user group and within the group of representatives from the local and regional administration, in order to identify the particular challenges, viewpoints and suggestions of each group. Dia-

36 Global Water Partnership Central and Eastern Europe, What is IWRM?, https://www.gwp.org/en/ GWP-CEE/about/why/what-is-iwrm/, accessed on 10 April 2020. The Global Water Partnership (GWP) is a global action network with over 3000 partner organisations in 179 countries.

37 Cf. Collective Leadership Institute, Une gestion intégrée des ressources en eau en Tunisie, Potsdam, 2016, http:/www.collectiveleadership.de/wp-content/uploads/2018/11/CLI_ref_Tunisie_AG IRE_FRZ_2014-16.pdf, accessed on 30 August 2020; see also Collective Leadership Institute, Rapport Final: Gestion intégrée des ressources en eau: établissement des structures de dialogue entre parties prenantes dans le secteur de l'eau en Tunisie, Potsdam/Tunis, 2016, for a description of the different steps of the dialogue process.

38 Katzmair, Harald, et al, AGIRE - Appui à la Gestion Intégrée des Ressources en Eau: Établir des structures de dialogue entre parties prenantes dans le secteur de l'eau en Tunisie. Analyse des Parties Prenantes Tunisie - Kairouan. Rapport Final, FASresearch, Vienna, 2014.

39 Participants in the focus groups were members of the Agricultural Development Groups, people identified by the sector heads ("Chef de Secteur", Arabic "Omda", heads of the smallest local administrative units) and people who had been identified by Katzmair et al, note 38, as being locally influential and socially accepted. In the focus groups, the idea of the multi-stakeholder platform was presented and people were asked to define criteria that would qualify mandated representatives; as a next step, voluntary user representatives were nominated. However, the dialogue process still allowed for interested user representatives to integrate at later stages. 
logue training for both the water users' group and the administration group focused on general communication techniques and on how to formulate and exchange views in a respectful and non-conflictive manner. The dialogue process also included creative elements, such as painting the current water and agricultural situation in Sbikha, and subsequently painting a joint vision of a more sustainable future. This type of exercise generated many ideas for potential solutions: in their picture, the users depicted water poor crops, greenhouse cultures, water-saving irrigation systems, and a local administration building with an open door and an official holding out his hand. After several months of dialogue facilitation in these separate groups, the "mixed dialogue" between water users, administration and a few other stakeholders such as representatives of the semi-private water company Société Nationale d'Exploitation et de Distribution des Eaux (SONEDE) was launched as the next stage of the dialogue process. ${ }^{40}$ This was a very sensitive phase of the process, since there was historically very little trust and a high risk of conflict between the two groups, as well as language barriers due to different levels of education and different verbal and non-verbal communication habits in the respective environments. In post-revolutionary central Tunisia, demonstrations, street blockades and sit-ins were frequent at the time, the administration being in a constant state of apprehension about protests potentially turning violent. An example illustrating such apprehensions is that at the beginning of the dialogue process, representatives of the Regional Agricultural Development Commissariat hardly ventured to undertake the 20-minute car drive to nearby Sbikha for fear of getting their car tires pierced by angry farmers who blamed the administration for depriving the region of water resources for the benefit of the tourist areas at the coast. Likewise, and despite the fact that some farmers did file complaints about illegal boreholes at the Regional Agricultural Development Commissariat, to most farmers it would not have occurred to just walk into the Commissariat trying to engage in a dialogue with the Commissioner in order to jointly search for a solution to their problem. A large part of the facilitation process between the two groups, therefore, focused on trust-building exercises before even beginning to talk about the actual governance challenges. Step by step, as part of the dialogue exercises, members of each group started sharing their perception of the water situation, including personal experience as well as the official facts and figures. The information shared not only included the regional administration's data on the development of the groundwater tables in the different aquifers, but also a user inventory of authorised and unauthorised boreholes, compiled by the water users as part of the dialogue activities: very sensitive information which the administration did not possess in its entirety, and could hardly have obtained without the help of the farmers.

40 The main lines of conflict being between the administration and water users, other stakeholders played a minor role. The water and electricity companies at the level of the governorate despite being invited either did not participate or sent representatives with little decision-making power. Representation of civil society associations was weak, since locally existing associations were often weak and inexperienced. 
The groups also shared their ideas and expectations about a better future, and about the related responsibilities of each of the parties involved. At every subsequent workshop, the different suggestions and expectations were discussed in a more and more specific way, up to a point where formulations for a joint agreement were proposed, discarded again or modified. At the very final stage of the dialogue, the stakeholders put their agreements together in a joint "Water Charter," a moral contract on the commitments that each party would respect. This Water Charter was publicly presented, discussed and signed at the first "Water Forum" in Sbikha on 24 and 25 May 2016, a festive event with over 300 participants. The signatory parties were the incumbent Minister of Agriculture himself, the Regional Agricultural Commissioner as head of the Agricultural Development Commissariat in Kairouan, and four representatives of the water users, one for each of the three relevant groundwater aquifers and one for the surface water resources. All four user representatives were at the same time either presidents of the respective Agricultural Development Groups or people of comparable influence.

\section{The Water Charter of Sbikha}

The Water Charter lists three concerned parties, (1) the network of water users of Sbikha and civil society, (2) local, regional and national administrative bodies responsible for water resources management and arbitration, and (3) other administrative bodies. ${ }^{41}$ The Charter defines guiding principles between these parties for participatory water management in the Sbikha region, it defines a governance structure for this water management by creating a Coordination Body, and finally lists a number of commitments and activities that the signatory parties plan to engage in.

The preamble of the Charter refers to the Tunisian Constitution, citing both the right to participate in elaborating development programmes guaranteed by Article 139, and the right to water provided for in Article 44 of the Constitution, "The right to water shall be guaranteed. The conservation and rational use of water are a duty of the state and society." 42

The signatory parties of the Charter state their conviction that, "The use of water resources is excessive and haphazard," that, "it is necessary to rationalize the exploitation of water resources to restore the balance of water systems," and, "of the need to strengthen collaboration and cooperation among water users, the administration and the Agricultural Development Groups to ensure greater efficiency in their collective work." 43

41 Such "other administrative bodies" were not more closely defined and in reality did not play a significant role in the stakeholder dialogue.

42 International IDEA, note 3.

43 Charte pour une Gestion Participative et un Arbitrage Local des Ressources en Eau de Sbikha, Sbikha, 2016. Original version in Tunisian Arabic, French translation contracted by GIZ and validated by the regional administration, translation from French to English by the project. 
When outlining the principles for water management in Sbikha, the Water Charter directly refers to the constitutional concept of "rational" water usage as a key concept for water use in the Nebhana catchment area.

"The stakeholders adopt and ratify the following principles:

- The right to water is constitutionally guaranteed;

- Water is a public property and a national asset; its preservation, rational use and valuation are a shared responsibility of all;

- Drinking water supply is an absolute priority;

- Adopting a participatory management for the rational use of water quotas allocated to the region; (...)"44

The Water Charter also makes reference to participatory management as guiding principle, highlighting the importance of dialogue and cooperation. In order to establish a governance structure for this cooperation, it specifies that, "All parties concerned are committed to:

- (...) Set up a 'Coordinating Body for participatory water management';

- Entrusting the Coordinating Body with supervising the compliance with the quotas allocated to Sbikha, and ensuring their fair distribution;

- Entrusting the Coordinating Body with settling and distributing the water quotas reserved for it from the Nebhana dam, as well as defining mechanisms for monitoring the annual abstraction of ground water in accordance with the proposed and approved cultivation programmes;

- Ensuring the implementation of action programs agreed at the Water Forum and during periodic dialogues; $(\ldots)^{45}$

The establishment of this Coordination Body is a key result of the dialogue process. The Coordination Body is intended to function as a local arbitration mechanism - a committee with mandated members of the administration and the water user groups, which is charged with deciding about the local distribution of the water quota allocated to the intervention area by the national Ministry, according to predefined priorities. These priorities are not listed in the Charter, but had already been defined by the stakeholder groups in the dialogue process: Thus, the allocation of household drinking water was defined as first priority, the second priority was providing water for irrigating tree cultures such as olives and apricots, and the third and further priorities were providing water for vegetable cultures and other crops classified in a specific order. ${ }^{46}$

44 Charte pour une Gestion Participative et un Arbitrage Local des Ressources en Eau de Sbikha, note 43.

45 Charte pour une Gestion Participative et un Arbitrage Local des Ressources en Eau de Sbikha, note 43 .

46 Presentations prepared and presented by the stakeholder groups at the Water Forum in Sbikha, 24 and 25 May 2016. 
Finally, the Charter proposes different actions towards restoring the water balance and further improving local water management.

- "Producing, collecting, and disseminating the data related to water in the area of intervention, and realizing the relevant surveys and trainings to preserve the water resources;

- Preserving jointly the public water facilities and systems and ensuring their maintenance; in exceptional circumstances such as floods, the administration will take the necessary measures;

- Encouraging the adoption of water-saving crops and promoting investments aimed at saving water resources;

- Supporting and expanding the adoption of water saving irrigation techniques." 47

The Charter highlights the importance of making reliable data available through collaboration between the administration and the users. A very important commitment by the users made in the dialogue process - even if not specified in the charter - is to apply auto-control, also with respect to unauthorised boreholes. In the Charter's Preamble it is mentioned that the signatory parties are convinced "of the growing number of infringements that take place in the public water domain and the need to support the administrative structures in order to enable them to adequately deal with this phenomenon": this indirectly refers to the users' commitment to auto-control and compliance with the existing legislation on how to obtain authorisations for boreholes. ${ }^{48}$

The Water Forum with its signature of the Water Charter was perceived as a big milestone by many of the different stakeholders, marking the success of the dialogue process with a formal agreement and an organisational structure for its implementation. It was also a fascinating moment for many of its participants, because there seemed to be so much momentum and commitment by the different parties involved, and because it illustrated the tangible results of a months-long cooperation between government and population, characterised by mutual trust and respect - a type of collaboration that was previously unheard of in the region, given the authoritarian past as well as both parties' apprehensions and mistrust following the revolution. The fact that the Water Forum as an event took place in the small agricultural town of Sbikha - not in the national capital Tunis, or even the regional capital Kairouan - and the fact that the Minister of Agriculture himself travelled and attended the meeting in this rural location, were highly symbolic for local water users. Expectations on the future benefits of strengthened cooperation between local water users and the administration, from local up to national level, were very high. What was also striking in the drafting process of the Charter was that the stakeholder dialogue group developed something sounding like a legal text, albeit with unclear legal status and legal relevance. It clearly was considered to be a moral, not a legal, commitment by the signatory parties, yet,

47 Charte pour une Gestion Participative et un Arbitrage Local des Ressources en Eau de Sbikha, note 43.

48 Charte pour une Gestion Participative et un Arbitrage Local des Ressources en Eau de Sbikha, note 43. 
the discussions about every single phrasing and the ceremony around the signature seemed to suggest that a pilot commitment was being developed here which over time, or merely by customary and practical respect of its provisions, might solidify into something with legal status. However, a number of challenges rendered it difficult to apply the provisions of the Charter immediately. These challenges, as well as some positive outcomes, are discussed in the next section.

\section{Challenges}

a) The relation between the Charter and existing law

One type of challenge in the water dialogue process can be characterised as a tension between the status of the Water Charter and the ideas of the stakeholders on the one hand, and the existing and developing law in Tunisia, on the other hand. When passing to the implementation of the provisions of the Water Charter, it turned out to be a main challenge that there was no legal form for the Coordination Committee that had been agreed on: no legal provision for such a mixed committee could be found. Members of the administration participating in the dialogue explained that the only form for such a committee existing in Tunisian law would be an association, consisting only of members of civil society: no "mixed" associations with representatives from the administration as well as civil society existed legally in Tunisia. It remained unclear whether those members of the administration who had participated in drafting the Charter were unaware of this obstacle at first, or had simply hoped to succeed with an approach that would first create a useful status quo at the local level for which the formal legal basis could then be identified or created afterwards. Whether real or asserted obstacle, the lack of a formal legal provision prevented passing to action with the creation of the Committee for some time, and induced the cooperation project to contract a legal expert in order to analyse the legal basis and make suggestions for how the Committee could be institutionalised and anchored.

Furthermore, the Water Forum and dialogue process took place while the new Tunisian Water Code was under development. Especially the stakeholders from the side of the administration in the dialogue were waiting for new regulations, in particular the mechanisms of sanction for infractions such as the unauthorised use of groundwater, which would be announced with the new Water Code. The project of reforming the legal framework on water in Tunisia dates back to a World Bank study of 2009. The first draft for a new Water Code was discussed in 2014 and since then underwent numerous modifications, until the final draft of the Code was submitted to the Ministerial Council in May 2019. ${ }^{49}$ At the time of writing, the Code still has not been passed.

49 Observatoire Tunisien de l'Economie, Policy Brief No 6, 4.8.2019, Politique de l'eau: le nouveau code des eaux saura-t-il répondre à la crise de l'eau en Tunisie? http://www.economie-tunisie.org/s ites/default/files/20190808-pb_cde-bap.pdf, accessed on 24 May 2020, p. 2. 
b) Challenges in local legal enforcement

The Charter mentioned infringements in the public water domain, and the need to support the administration in coping with these, but how exactly this could happen remained to be specified. Apart from expecting more compliance from the users as a result of the dialogue process, the administration also hoped for more severe possibilities of sanctions to become available with the new Water Code. It is questionable, however, whether, or how soon, a new Water Code with new mechanisms of sanction will be able to remedy the problem of uncontrolled drilling for groundwater in the governorate of Kairouan, or other infractions that the governorate is struggling with. While it is true that fines for an unauthorised borehole are currently not very high, ${ }^{50}$ a consistent implementation of the already existing possibilities of sanction is part of the challenge, too.

Unauthorised boreholes are a point of contention for those water users in Kairouan who have authorised boreholes, since their neighbours thus freely access a scarce resource, and the effects of the sinking ground water level have become widely felt for everybody, for example as a necessity for ever stronger pumps and deeper drilling. According to local data, approximately 500 complaints about users with unauthorised boreholes are filed per year at the Regional Agricultural Development Commissariat of Kairouan. The latter, however, has not had the capacity to follow up on these complaints. From 2018 to 2019, the position of the person responsible for the unit handling such cases in the Commissariat was vacant. ${ }^{51}$

However, the lack of rigour in following up on the complaints is probably not only due to a lack of human resources and legal and procedural knowledge. The local authorities also know very well that many farmers do not have very many other options than using water resources for their existential agricultural livelihoods, and are reluctant to rigorously enforce the law for that reason. In the project region, there were reports of farmers receiving police officers with a can of fuel in their hand, threatening to put themselves on fire and commit suicide if their water pump were confiscated - just like Mohammed Bouazizi, whose self-immolation has become a symbol for the start of the Tunisian revolution. In the conflict-sensitive post-revolutionary context described earlier, such a threat understandably could be enough to make a police officer return without pursuing his initial intention. There were other reports of farmers hiding their pump because someone had informed them that a police officer was on his way to confiscate it: informal networks and local corruption also play roles in local law enforcement that should be more closely examined.

50 Cf. Haddad, Mohamed, En Tunisie, les plantations de petits pois assèchent les autres cultures, in Le Monde Afrique, 16.12.2016, https://www.lemonde.fr/afrique/article/2016/12/16/en-tunisie-lesplantations-de-petits-pois-assechent-les-autres-cultures_5049974_3212.html, accessed on 24 May 2020.

51 The responsible unit is the "cellule contentieux" of the Regional Agricultural Development Commissariat. Information on complaints data and response by Kairouan-based GIZ expert in the programme "Support to integrated water resource management"; conversation with the author on 30 October 2019. 
c) A lack of sufficient, continuously available and dedicated core stakeholders

The continuous availability of a sufficiently large core group of participants in the stakeholder dialogue was another challenge in the process. Certain officials in the regional and local administrations were very much committed to the dialogue process, but at the time of the first Water Forum, the process was not yet at a stage where it had institutionalised. Rather, it depended on the personal commitment of certain individuals. Therefore, when rotations occurred - something happening quite frequently at the level of Regional Commissioners and of the Division Heads within the Commissariat - the successors of the original participants of the stakeholder dialogue again had to become familiar with the process and buy into it. There was also a general challenge regarding the availability of human resources both on the administration and the user side to continue investing so much time as had been invested in this Water Forum process prior to the signature of the Charter: it became obvious at that time that even for the most committed participants, their contribution to the dialogue process as an activity that had been on top of their usual workload would have to start paying off in terms of tangible improvements in their core area of work, be it agriculture or the administration of regional water resources.

\section{d) The impact of national level decisions}

Finally, throughout the whole dialogue process, it became very clear that the regional authorities were very much dependant on the support of the national Agricultural Ministry for any local or regional agreement emanating from the dialogue. Yet the Agricultural Ministry was not always acting in a coherent way with what the stakeholders of the Water Forum developed and suggested. The summer after the first Water Forum event of May 2016 brought a period of drought. Only a week after the Forum, on the first of June 2016, the Directorate responsible for dams and large hydraulic works in the Ministry of Agriculture decided to close the Nebhana Dam, which was almost empty after several dry years. ${ }^{52}$ The surface water quota subsequently allocated to the region by the national Ministry was enough to cover only an estimated 30 percent of the need of the farmers in Kairouan according to their agricultural plans. With such a low degree of coverage, it turned out to be impossible to practise local arbitration as had been intended by the Water Charter. ${ }^{53}$ Instead, a whole new and unregulated market in trading groundwater resources ensued in a part of the catchment area that the Sbikha forum process was dealing with.

52 Chennaoui, Henda, 25.6.2016, Les citronniers de Sbikha ont soif, https://nawaat.org/portail/2016/0 6/25/les-citronniers-de-sbikha-ont-soif/, accessed on 24 May 2020, and Haddad, Mohamed, note 50.

53 Information from Kairouan-based project expert in the GIZ water programme, conversation in November 2019. 
e) Conflict mitigation as a positive result of the dialogue

On the other hand, a very positive aspect of the dialogue process that was highlighted by some local observers was probably its contribution to conflict mitigation: ${ }^{54}$ These observers said that without the Water Forum process that had preceded the drought, there would certainly have been more tensions, conflicts and protests in the region as a reaction to the closure of the dam. The dialogue had perhaps contributed to a general understanding among the farmers that water resources in Tunisia were scarce and finite, and that many forms of agriculture practiced in the region were not well adapted to the local climate and the availability of this scarce resource. ${ }^{55}$

One element of the farmers' criticism towards the administration, whether voiced in a dialogue or through demonstrations and protests, had always been their dissatisfaction with the water distribution, particularly the resources from the Nebhana Dam, between the central region and the coast. The decision-making criteria for defining the distribution of surface water resources between regions, and the final distribution quota itself, had never been communicated openly and transparently by the national government. In a situation where a dialogue process had raised the population's expectations on transparency and predictability of government decisions very much, the Agricultural Ministry's reaction to the drought with the closure of the dam and the allocation of an unexpectedly small regional water quota became less plausible and more difficult to defend even for the Regional Commissioner, who is part of the Ministry's hierarchical structure. Yet, this Regional Commissioner had gained considerable trust locally through the dialogue process with the local citizen, and was thereby able to mediate and justify the Ministry's decisions. Furthermore, during the dialogue process and prior to the first Water Forum, some farmers had, of their own initiative, already addressed a letter to the Ministry asking for certain measures to be taken - an initiative that would certainly have been less likely without the preceding dialogue.

\section{f) Demand versus supply management: incoherent political communication}

From its beginning, the Water Forum approach at the regional level had been conceived as an approach of demand management: economising water consumption rather than increasing resource availability. However, while the Regional Agricultural Commissioner did engage in discussions with the farmers about the best approach to manage water scarcity, the responsible officials at national level were perhaps not ready at the time to engage with the population to such an extent. And if awareness about water scarcity and the importance of demand management had been raised regionally, at a national level the government was never outspoken about the actual water situation in Tunisia: from the past to the time of writing, messages from the Agricultural Ministry usually focused on the state's capacity to

54 Cf. also GIZ, Managing water resources and raising awareness, https://www.giz.de/en/worldwide/ 62164.html, accessed on 25 May 2020. 
provide sufficient water resources and to increase supply, rather than acknowledging the problem of acute scarcity, an unsustainable and ecologically detrimental overuse, and the difficulties of managing an ever-rising demand. ${ }^{56}$ At the Water Forum, the Agricultural Minister mentioned an on-going study about the possibilities of transferring surface water from Northern Tunisia to the central region. Unsurprisingly then, the Forum created high expectations among the water users towards the Agricultural Ministry for solving the regional problems by offering greater water supplies, even by building more large-scale infrastructure and transferring water resources from the North of the country to Kairouan. ${ }^{57}$

While it is understandable that any government would prefer communicating to the public about its capacity to solve problems rather than about the challenges it is facing, such an approach could paradoxically lead to more protests by the population: obviously, those citizen who had always been told that there were abundant water resources in Tunisia would blame the government if this abundance did not manifest in their houses and their fields. To some extent, this illustrates the dilemma of a government that has been very successful with a supply management approach for a long time. The difficulty of publicly communicating about water scarcity nowadays can be seen as a detrimental side-effect of the general success of the Tunisian government in providing sufficient or nearly sufficient water resources for many years, having invested in large-scale infrastructure that allowed the exploitation of 90 percent of the available water resources. ${ }^{58}$ The government's public communication in the face of the drought in 2016, then, sounded rather helpless at points when officials said that they would "wait until the rain falls again" and organise "prayers for the rain." 59

56 For example, in 2016, the Agricultural Ministry announced a costly new programme of constructing four stations for desalination at Tunisia's eastern coast and two new dams, cf. Webmanagercenter, Tunisie, 16.11.2016: Face à une situation hydrique inquiétante, Abdallah Rabhi se veut plutôt rassurant, https://www.webmanagercenter.com/2016/11/16/398001/abdallah-rabhi-la-tunisie -est-sous-hydrique-mais-la-situation-est-toujours-gerable/, accessed on 25 May 2020. Cf. also Webmanagercenter, 25.1.2020, Plus de 5 milliards de dinars ont été alloués au secteur de l'eau en Tunisie depuis 2016 (Rabhi), https://www.webmanagercenter.com/2020/01/25/444016/plus-de-5milliards-de-dinars-ont-ete-alloues-au-secteur-de-leau-en-tunisie-depuis-2016-rabhi/, accessed on 25 May 2020.

57 Cf. also Haddad, note 50.

58 Besbes, Mustapha, et al, "L'eau en Tunisie", Tunis 2013, https://www.pseau.org/outils/ouvrages/e nit_1_eau_en_tunisie_2012.pdf, p. 3, accessed on 30 August 2020; cf. also Slama, Fairouz, and Jamel Chahed, "Water Security in Tunisia: Debated Issues", Tunis 2019, https://globalwaterforum. org/2019/08/05/water-security-in-tunisia-debated-issues/, accessed on 30 August 2020. There is arguably also a built-in systemic conflict of interest in the fact that the responsibility for water management is situated in the Ministry of Agriculture in Tunisia, rather than, for example, in the Environmental Ministry. The Ministry of Agriculture is expected to mitigate water demand in a situation of extreme scarcity, while one of its main purposes is promoting the development of agriculture, water's greatest consumer. A number of agricultural subvention schemes offered by the government are in contradiction to a water demand management approach.

59 Cf. Chennaoui, note 52, "In Tunis, Abdallah Cherid, General Director of Dams and Large Hydraulic Works, dements the lack of maintenance of the Nebhana dam. 'We have provisionally 
In conclusion, while the Water Stakeholder Dialogue served to appease tensions around water resources locally, the combination of the challenges described here - an incoherent communication, an unclear level of commitment to the dialogue process by the national level administration, a lack of sufficient continuously available core stakeholders, legislation still under development, challenges in applying the existing law, and challenging natural circumstances - led to some rupture in the dialogue process after the first Water Forum and slowed down the implementation of the next steps, such as the creation of a functional Coordination Body.

In the following section, the second example of citizen participation will be presented. While the character and duration of citizen participation in this example is very different from the example discussed above, both examples present some interesting similarities that will be described in the final section.

\section{Example 2: Citizen participation in regional development}

\section{The project background}

In this second example, citizen participation in planning small-scale investments in regional infrastructure and services will be discussed, based on experiences from the project "Initiative for Regional Development in Tunisia." This project is an initiative conceived to accompany the decentralisation process in Tunisia by investments that lead to tangible improvements in basic public infrastructure in the disadvantaged interior regions. With funds from the BMZ, this project finances the construction of school canteens, sports grounds, basic health centres, and extensions for regional hospitals, and provides equipment for schools and health centres, youth centres, and people with special needs. It also funds local subsidies to civil society organisations that invest in income-creating activities for poor population groups. The project is implemented by GIZ and carried out in cooperation with the Ministry of Development, Investment and International Cooperation (MDICI) at the national level, ${ }^{60}$ and with numerous regional partners. The intention of both the Tunisian and the German government is to use this project to show the population in post-revolutionary Tunisia that positive change is happening, improving every-day living conditions in core sectors in some of the most deprived areas. It is assumed that thereby, apart from the direct benefits through improved social infrastructure, the trust between the regional administration responsible for such projects and the population in the interior governorates will be enhanced. At the same time, the objective of the project is to support and train participatory

closed it, waiting for the rain", and Haddad, note 50, "The response of the government, through the Ministry of Religious Affairs, has been to organise "prayers for the rain". The Almighty has heard them, but too late, the rains arrived in October and have not been sufficient to fill the dam". Both quotations translated from French by the author.

60 Cf. http://www.mdici.gov.tn/en/, accessed on 10 October 2020, for further information on the Ministry. Since September 2020, the former structures of the MDICI have been incorporated into the Ministry of Economy, Finances and Investment Promotion, cf. note 26 above. 
decision-making at a regional level through Regional Steering Committees and through citizen debates, in order to practice and pilot participatory democracy as it is envisaged by the Tunisian Constitution of 2014. The project intervenes in eight governorates in North-Western, Central and Southern Tunisia: Béja, Jendouba, Kef, Siliana, Kairouan, Sidi Bou Zid, Kasserine and Medenine. At the time of writing, over 60 individual regional projects financed by the Initiative for Regional Development have been implemented. ${ }^{61}$

\section{Participatory decision making about small-scale investments}

The main decision-making bodies of the project are National and Regional Steering Committees, the "Comitée de Pilotage National" and a "Comitée de Pilotage Régional" for each of the eight governorates where the project is being implemented. The members of the Regional Steering Committees are representatives of the deconcentrated sector administrations such as the Regional Educational Commissariat, the Regional Health Department, the Regional Social Affairs Department etc., as well as representatives of selected civil society organisations and, since the municipal elections in 2018, selected Mayors or members of the Municipal Councils of the particular municipalities where the project intervenes. ${ }^{62}$ The Governor heads the Committee. The Regional Development Director, who in organisational terms belongs to the structure of the MDICI, has a key role in coordinating between the Committee members, and facilitating its meetings. ${ }^{63}$

The participatory project identification procedure developed jointly by the administration and GIZ project staff consists in several steps, including citizen debates. According to the current "third phase" approach of the project, as a first step in the preparation of a regional development project, the Regional Steering Committee predefines the beneficiary group and intervention zones according to criteria determined by the representatives of the Committee. ${ }^{64}$ Criteria that the Committees have been using are mainly the regional development indicators, e.g. statistics on unemployment, access to health services or access to

61 GIZ, Strengthening regional development in Tunisia, https://www.giz.de/en/worldwide/33302.htm 1, accessed on 25 May 2020; cf. also GIZ project documentation, e.g. GIZ/ Saidi, Adel, "Rapport de Capitalisation: Projet Initiative pour le Développement Régional”, Tunis, 2018.

62 GIZ, Projet Initiative pour le développement régional, Manuel de procédures adapté à la 3ème phase, Tunis, 2018.

63 The Regional Steering Committee remains, at the time of writing, a project structure. There are ongoing discussions about whether the structure could become a permanent structure used by the administration, independently of the presence of GIZ. Some of the project partners in the Ministry of Development, Investment and International Cooperation have stated their appreciation about the functioning mechanism of this Steering Committee, which is more flexible than the Regional Council: contrary to the Regional Council with fixed quarterly meeting dates, it can be called to meetings at short notice when needed, and different stakeholders can be more easily integrated upon invitation by the Governor. The Governor also ensures coherence between decisions of the Regional Steering Committee and the Regional Council.

64 GIZ, projet Initiative pour le développement régional, Orientations stratégiques du projet IDR Phase III, Tunis, 2018. 
education disaggregated by different population groups and zones. Another selection criterion was to exclude project types for which funding from other public funds could be provided by the Tunisian administration, so as to dedicate the funds of the Initiative for Regional Development to interventions that were not otherwise covered.

As a second step, after the beneficiary groups and zones of intervention had been defined, the project organised citizen debates with members of the beneficiary groups in order to discuss their specific situation and challenges with them, develop project ideas with them in the frame of the available funding, and prioritise between these ideas. The participants of these debates were individuals and civil society organisations invited by the local authorities. "Civil society" is diverse, of course. In the case of this project, the civil society organisations represented were mostly certain interest groups or associations, such as the "Association Enfants de la lune de Médenine" or the "Parents of Children with Autism" in Kef. The local authorities, usually the local delegate and the sector heads, ${ }^{65}$ would also invite locally influential individuals and people known to be socially committed and active. Sometimes the participants were membership groups, e.g. members of a youth centre, if the project addressed the youth in a certain area as beneficiary group. The number of citizen in the debates varied between less than 10 and more than 70 participants.

Sample projects suggested in these citizen debates that took place from 2018 to 2019 were very similar to the projects that had been funded in previous phases of the Initiative for Regional Development: participants suggested buying equipment for a youth centre and a cultural centre, providing medical equipment for a centre for dialysis, furnishing cars and equipment for mobile medical services in mountainous areas, providing equipment for a centre for children with hearing impairments, and other types of equipment for the benefit of people affected by certain diseases or disabilities. After the citizen debates, the project ideas were presented to the Regional Steering Committees in the order of priority established by the participants of the debates, who then discussed the feasibility and detailed concepts for each project, and voted on the final choice of projects on the basis of project fact sheets developed by the representatives of the respective sector administrations. After validation by the Regional Steering Committee, the project fact sheets were presented to the National Steering Committee for final validation. This sometimes resulted in modifications at the technical level - e.g. modifications of project objectives and indicators, or comments on specialised institutions that should be involved in the implementation - but the National Steering Committee usually accepted the project proposals as such. This perhaps demonstrates a certain level of acceptance of the principle of subsidiarity, leaving decisions about social infrastructure investments to the governorates. The following paragraph discusses some of the challenges that could be observed regarding direct citizen participation in the decision-making processes in the frame of the Initiative for Regional Development. 


\section{Challenges}

a) Representation and democratic legitimacy

If citizen participation is to increase government transparency and legitimacy, a crucial question appears to be who participates in citizen debates, and who speaks on behalf of whom. From a socio-anthropological perspective, the fact that local authorities choose who to invite to the debates poses a risk: the choice could be biased or not fully inclusive of certain groups. During the implementation of the cooperation project, it was discussed with the Tunisian authorities whether it would be possible to make the debates more open, e.g. by inviting people through public announcements. However, fears were that completely open debates could produce unmanageable expectations and conflicts in the population, since the allocated project budgets for each intervention area and population group were very limited. Apart from that, fears of radical organisations or organisations that might not be cooperative were voiced. The local authorities therefore selected organisations which they knew had the experience and professional competence to realise the type of joint project in question, and civil society organisations that were known to be active and publicly respected in the locality.

Another question concerns the democratic legitimacy and representativeness of the participants in the citizen debates. Thus, one of the questions discussed during project implementation was why there seemed to be more trust in civil society organisations than in the elected representatives of the Municipal Councils - after all, the latter were the democratically elected representatives of the local populations and should then arguably be the persons prioritising which local projects should be funded. However, different project stakeholders argued that civil society members in many settings were more trusted by the population than the Municipal Councils, since they worked on a voluntary basis, investing their own time and resources for the benefit of the population. They argued that on the other hand there was - probably related to Tunisian political history - not very much trust in elected representatives, but rather a suspicion that these might only act for their own personal benefit as soon as they got into office. ${ }^{66}$ At the same time, some municipal authorities are reported to have been able to gain very much trust through their actions since the 2018 elections. This should be more deeply analysed in the future in order to obtain a more differentiated picture.

66 This assumption may be indicative of the political dissatisfaction and frustration that different studies and political observers have noted at a larger level in Tunisia, prior to and after the 2019 elections. Cf. Ayari, Michael Béchir, La Tunisie se rend aux urnes dans un contexte délétère, in: International Crisis Group, Briefing, Middle East \& North Africa, Tunis, 2019, https://www.crisisg roup.org/middle-east-north-africa/north-africa/tunisia/la-tunisie-se-rend-aux-urnes-dans-un-context e-deletere, accessed on 30 August 2020. 


\section{b) Bargaining power}

When considering on an individual level who spoke in the citizen debates, from a socioanthropological point of view there are many questions to be analysed in relation to gender, age and class hierarchies and local power relations in general. In one debate in a NorthWestern governorate, for example, it could be observed that one very powerful individual was trying to monopolise the choice of the projects in order to "gain" a project benefitting his own interests and those of a small interest group behind him: His project proposal was to equip a group of purportedly poor fishers in a remote region with motor boats, a small cooling house for their catch, and further equipment. Through verification by the GIZ project team in coordination with the local and regional authorities it turned out that this group of fishers was not poor, most of them also were not registered or known to the local authorities with their fishing activity, their speaker was the owner of a profitable restaurant, and numerous other factors proved that the project proposal did not at all correspond to the determined selection criteria or general sustainability criteria for the choice of projects. Only then, and with the support of the Governor, did a different choice become possible. ${ }^{67}$

The local power structure also became visible in the role the Governor played in the choice of projects. This became particularly clear in one governorate, where five project ideas had been developed and ranked in order of priority as the result of the citizen debates. The Governor first prioritised two of them, and then only one project that he really wanted to be funded. The priorities of the Governor were presented to and validated by the Regional Steering Committee, so the Governor did not take a unilateral decision. Also, the number of projects was reduced from the initially selected two to one because different funds from the Ministry of Health had become available for the other of the two projects, so this was a logical decision. What was striking, however, was that whichever priority the Governor presented in the two consecutive sessions of the Steering Committee, the Steering Committee agreed unanimously. This suggests how powerful traditional roles and power structures in the region still are despite recent democratisation. While on the one hand this might be considered a risk for respecting the needs of the population, it should be emphasised that the Governor did choose one of the project ideas developed in the citizen debates, albeit not the citizens' first priority. ${ }^{68}$ In the example of the fishery project, the power of the Governor helped to counterbalance the power of a regional businessman with apparently influential allies, whom some of the other members of the administration in the Regional Steering Committee would not or could not speak up against.

67 Internal GIZ project documentation, project proposals and fact-finding missions for fishery project. In a context where similar motorboats have been transporting migrants from the Tunisian coasts to Europe, such a project proposal was politically particularly sensitive, of course.

68 Internal GIZ project documentation on the respective citizen debate in 2018, and on Steering Committee Meetings in 2019. 


\section{Conclusions}

The examples described above, of citizen participation in water management in central Tunisia, and citizen participation in developing small-scale regional development projects, suggest a number of conditions for implementing the Tunisian constitutional provision on participatory democracy successfully: facilitation, inclusiveness, transparency, and expectation management are to be named here, as well as commitment from all levels of the administration. The examples also illustrate, at a local level, certain areas of tension emanating from the larger political and legal developments currently on-going in Tunisia: tensions between the influence of an authoritarian socialisation and new democratic ambitions and rules, explicit and implicit bargaining about the distribution of power between centre, region and municipality, an asynchronous implementation of decentralised governance approaches in different regions, and the somewhat questionable juxtaposition of dialogue with conflict and protest. The following paragraphs summarise the success factors observed, as well as the challenges and areas of tension in the larger democratisation context.

\section{Conditions for successful citizen participation}

\section{Facilitation and inclusiveness}

In both examples of citizen participation described above, there was a need for trust building and for some extent of external facilitation for the participatory processes. In the postrevolutionary context of Tunisia as a country with an authoritarian past, trust between the population and the public administration was not at all evident, and apprehensions about potential conflict, as well as a mere uncertainty about how to proceed, were widespread. In such a context, participatory approaches such as the water dialogue process need time to grow, dialogue skills need to be practiced, and trust needs time to build. In the example of the water project, external facilitation and dialogue trainings proved very useful for establishing this trust and dialogue practice, and the proximity and local knowledge of Tunisian facilitators such as the sociologist who conceptualised and moderated a great part of the water dialogue process, were extremely important in order to understand local power structures, as well as what was sometimes being played behind the scenes. For example, prior to the Water Forum event in May 2016, some stakeholders started preparing banners with Qur'an quotations related to valuing and saving water, that were to be displayed during the Forum event. This was not a politically neutral action, as one might think in a country with an overwhelmingly Muslim population majority. As the sociologist and facilitator explained, such banners would immediately have been associated with the conservative Islamic party Ennahda, who had used Qur'an quotations previously in election campaigns. The core group of administration and water user representatives in the stakeholder dialogue absolutely did not want the dialogue process to become hijacked for party politics, and therefore blocked the banner initiative. 
In the case of the Initiative for Regional Development, time constraints and the focus on quickly visible results did not allow for a comparably long-term dialogue process as it was realised in the water project. However, the decisions at stake were also much less controversial than the conflict-ridden topic of water governance. Risks of conflicts in the population were minimised by holding citizen debates directly with the pre-selected beneficiary groups, rather than between different population groups who would then have had to negotiate about how to divide a fixed sum of money between them. The project benefitted from the fact that offering a budget to a pre-determined population group in order to make investments into infrastructure or equipment directly improving their living conditions will rarely meet with disagreement from that particular group. By selecting experienced and respected local NGOs as civil society representatives in the debates, and as implementation partners, many governorates chose an easy way of establishing multi-actor partnerships. In some governorates GIZ functioned as facilitator to initiate such cooperation: some Governors completely avoided inviting civil society organisations to the Regional Steering Committees until GIZ created contacts to particular associations representing the beneficiary groups. ${ }^{69}$ Afterwards, collaboration between the regional administration and these associations was successfully established.

Inclusiveness to the greatest possible extent is another important precondition for participatory governance: citizen participation in local governance should be free from discrimination. The water project strove to ensure this inclusiveness through a long preparatory process for the dialogue, which combined sociological analyses of the population in the region with focus group discussions. Throughout the dialogue, even after the identification of mandated water users, the process remained open for integrating newcomers who had heard of the dialogue and were interested in joining the debates. The regional development project, too, aimed at creating inclusive debates by crosschecking different sources for whom to invite, and relying not only on the local authorities for selecting participants. Yet, the representativeness and legitimacy of particular participants or groups in a participatory process, as well as their individual and collective bargaining power, need very close attention and analysis in each specific setting, as the examples have illustrated. In both cases, powerful individuals or groups tried to divert and manipulate the dialogue process for their own particular interests, as the examples of the Qur' an quotations and the fishermen project have highlighted. In such cases, a competent external facilitator can help both to see through power structures and manipulation strategies in the first place, and to strengthen the

69 Something further complicating the participation of civil society organisations in Regional Steering Committees seems to have been the fact that quite a few civil society organisations in Tunisia are purportedly acting as civil agents of political parties. One Governor explained his view on his dilemma, arguing that once he opened up the Regional Steering Committee for civil society organisations other than representatives of specific interest groups who had been preselected as direct project partners, he would receive massive criticism for his selection of organisations and protest from those not invited, and there would be no end to the discussion. Since in his view the Regional Steering Committee could never accommodate all potentially interested organisations, according to him it was better not to invite even one. 
voice of less confident or less powerful individuals and groups. For instance, in the water dialogue process, dialogue facilitation in separate groups before entering the "mixed" dialogue with the administration helped the water users to express and collect their views while protecting their individual privacy, regarding sensitive topics that they would not individually have wanted to address in front of the administration. The users' views and suggestions - the result of a facilitated discussion about their individual ideas - could then be given to the administration as a summary presentation without uncomfortably exposing individual farmers.

In the example of the water dialogue process, it was observable how some participants, especially representatives of the water user group, gained more and more confidence over time to voice their views. A case in point was the example of one female farmer who publicly spoke about the users' water saving suggestions in front of three hundred participants at the Water Forum event, something she would never have dreamed of doing only a year before. A similar novelty was the letter sent by local farmers directly to the Agricultural Ministry, voicing their demands. While this was an independent action, which had not been facilitated or collectively agreed on in the dialogue process, this group of farmers certainly felt more confident to try such an action after having entered into a direct dialogue with the regional administration already. Facilitated participatory processes, thus, can empower people to publicly voice their opinions and concerns, and have an intrinsic value "insofar as taking part in community decision making also builds capacity for self-reliance and collective action ... When successful, participation can transform passive residents into effective public citizens, who use it as a tool to hold states and markets accountable and influence decisions that affect their lives." ${ }^{, 70}$ Another potential benefit is that citizen who have been involved in planning and realising local constructions like school canteens or youth centres can be expected to feel more ownership for such infrastructure, and take better care of it in consequence.

\section{Transparency, expectation management and commitment}

Apart from the intrinsic value of empowering citizen, and positive side effects such as conflict mitigation, that were observable in the drought time after the water dialogue process, citizen participation should of course result in tangible results in terms of the political decisions taken. At the same time, it is very important to define well from the beginning what the scope of influence of a participatory process with the population can be - and which decisions are beyond the citizens' influence. Transparency and expectation management appear to be very important conditions for success here, as well as some real commitment by the authorities involved, since "public participation can only contribute to government le-

70 Mansuri, Ghazala, and Vijayendra Rao, Localizing development: Does participation work? A World Bank policy research report, Washington D.C., 2013, p. 16. 
gitimacy if it has a genuine impact on political decisions." 71 Based mainly on research in West Africa, Lierl observes that citizens are often estranged from the state not for lack of opportunities to participate, but "due rather to the low likelihood that participation would make a difference in a political system that is organised along clientelistic structures." 72 Such frustrations or "participation fatigue" are a risk in any context where citizen participation mechanisms are envisaged as part of political decision-making. Participation needs to offer real solutions to citizens' actual problems in order to justify their engagement and be beneficial and empowering in the long run. ${ }^{73}$ In contrast to Lierl's findings, however, the examples discussed here do not appear so much to illustrate clientelistic structures, but rather power struggles, and undefined scopes of influence, between the national and the regional level of the administration in Tunisia. These power struggles and ambiguities could be illustrative of the on-going decentralisation process.

Both projects described above from the beginning took into account the risk that expectations could be raised too high in the process. In the citizen debates around planning regional investments, the GIZ project attached importance to communicating transparently how funding decisions for projects were taken, and what the budget limitations were. In the case of the water project, expectations by the water users at the time of the Water Forum in May 2016 had certainly become very high, including expectations on larger water quota to be allocated to the region. This was not something that the regional administration had intended to result from the dialogue - the emphasis in the regional stakeholder dialogue had been on the necessity of managing a scarce resource, on demand management. However, some incoherent communication by the national level administration contributed to raising expectations about greater water supplies. In addition, these expectations perhaps also illustrate an effect of the citizens' socialisation in an authoritarian system. Direct contact to representatives of the administration, such as had been established by the water dialogue process, traditionally would have been very valuable as something that could result in immediate personal benefits. Now, voicing needs and demands directly to the Agricultural Minister during the Forum event should logically result in some governmental action towards the advantage of the regional population in Sbikha/ Kairouan. This would have corresponded to the citizens' prior experience, since the visits of Ministers or high officials to a particular location in Tunisia often seem to come with promises of direct support for that location, especially in election times. At the same time, while the national government disappointed some expectations emanating from the stakeholder dialogue on water governance in Kairouan, it was observable that at a regional and local level, there was a true willingness among officials to take participation seriously and engage citizen in water governance in a

71 Lierl, Malte, Promoting good governance in Africa - Three popular misconceptions, in: Basedau, Matthias, GIGA Focus Africa, No. 3, Hamburg 2019, p. 1.

72 Cf. Lierl, note 71, p. 5f.

73 Cf. Rauch, Theo, Nun partizipiert mal schön. Modediskurse in den Niederungen entwicklungspolitischer Praxis, Blätter des iz3w Nr. 213, 1996, p. $20 \mathrm{ff}$. 
way that would impact local decision-making. For example, one member of the Regional Agricultural Development Commissariat in Kairouan who was very committed to the Water Forum dialogue process said during the preparation of the Water Forum that he and others in the regional administration really wanted to do things differently (referring to a more democratic and participatory governance process), but did not yet have the experience or established methods to know how to go about that. ${ }^{74}$

However, it became clear in the process that the regional administration also did not dispose of all the necessary information and back-up from its own ministerial hierarchy to steer this process independently and take independent decisions in the frame of its responsibility. One challenge was the lack of transparency regarding the actual amount of water available for the region; in addition, the situation was aggravated by a summer of drought. When the Agricultural Ministry announced the quota allocated per region, with a bare $30 \%$ of the need for the agricultural plans in Kairouan covered, even the Regional Agricultural Commissioner, despite his understanding of the drought situation, seemed to feel passed over and consider this a decision undermining the work that had been invested in the dialogue process. More research and analysis would be needed to determine how decisionmaking power on questions of resource management should be - and actually is - distributed between the national and regional level in Tunisia. What has become clear from the example is that while the regional administration strove to enhance its legitimacy by trying out a participatory approach to solving a problem with which it was immediately confronted on a daily basis, the national administration was perhaps too remote from the regional issues, and considered its stakes too high for ceding more power or offering more transparency. While it is obvious that certain decisions about distributing the national water resources have to be taken at national level - the Regional Commissioner did not have the competence to rule about the country-wide distribution of surface water resources - an impression still remained that the regional administrative level could have been more empowered and supported by its hierarchy, and a more open communication between both levels could perhaps have resulted in more political coherence. ${ }^{75}$ Whether the water stakeholder dialogue resulted in a permanent legitimacy increase for the regional administration therefore remained an open question.

In the case of the Initiative for Regional Development, it appeared that the participatory process and the investments resulting from that process actually contributed to enhancing the legitimacy of regional government representatives. Projects such as renovated school buildings or newly equipped health centres were very popular, and Governors, Regional Development Directors as well as Directors of the sector administrations considered that realising these investments had enhanced the population's trust towards them. The popularity of the investments and the struggle for credibility among the population were also visible

74 Conversation with a Division Head in the Regional Agricultural Development Commissariat of Kairouan in 2016, from the memory of the author.

75 Cf. also Collective Leadership Institute, note 37, p. $47 \mathrm{ff}$. 
through the fact that different local authorities competed in trying to appropriate the projects and present them as theirs: for example, some Mayors who had not been part of the Regional Steering Committees developing the regional investment projects before 2018, tried to present some of the finalised regional projects from early planning phases as "theirs" in order to enhance their own credibility and raise their popularity among the local population.

\section{Participatory governance in the context of on-going decentralisation and democratisation}

1. A back and forth between traditional power and new ambitions

The observations that have been made here for the local and regional level regarding areas of tension between traditional power and new democracy may reflect to some extent what political analysts are currently describing for Tunisia as a country, stating that Tunisia is in a hybrid situation between transformation and recurring autocratic elements. ${ }^{76}$

While the legal and political transformation in Tunisia is on-going, new legislation does not necessarily correspond to traditional power realities, and there is a discrepancy between the new, formal, written law, such as the constitutional provisions on participation in development planning, and the system that Tunisian authorities as well as the population have been socialised into - a system relying very much on the power of the central state and, in the regions, on the power monopoly of the Governor, who traditionally had a status like a regional president. ${ }^{77} \mathrm{~A}$ redefinition of roles, responsibilities and procedures is on-going as part of the decentralisation process. This became particularly clear in the instances where the Regional Agricultural Development Commissioner did not dispose of all the necessary information and transmission of power from his Ministry, but also where Regional Steering Committees agreed unanimously with any suggestion that a Governor would make.

Despite the fact that the Local Authorities' Code has been passed in 2018, it remains unclear in many areas how this will be put in practice. It is still very much a point of discussion what the future roles of the elected Municipal Councils - and Regional Councils - will

76 Cf. Gallien, Max, und Isabelle Werenfels, Tunesiens Demokratisierung: Erhebliche Gegenbewegungen, in: SWP Aktuell, Berlin 2019, p. 1, 5f.; cf. also Gallien and Salehi, note 10 and 12.

77 Béchir et al describe the role of the Governor as follows in 2011: "Le gouverneur représente d'une part l'administrateur général du gouvernorat qui est une autorité déconcentrée du ministère de l'intérieur, et d'autre part, il représente l'Etat tout entier. Le gouverneur est personnellement responsable de l'administration générale du gouvernorat." Béchir, Riadh, et al, Organisation Territoriale en Tunisie, Institut des Regions Arides de Medenine, 2011, http://cgdr.nat.tn/upload/files/15.pdf, accessed on 18 October 2020, p.16. Cf. Gallien, Max, und Isabelle Werenfels, note 76, p. 4ff., on conflicting developments in Tunisia and the role of established power networks as counter movements to the democratisation process. 
be in relation to the Governor, the deconcentrated regional authorities and the national government. $^{78}$

During the implementation process of the water project and the regional development project, at the regional level it was possible to observe a back and forth between the willingness to do things differently, in democratic and participatory ways, and the great apprehensions of the regional administration with respect to the accusations and demands they might face, or their apprehensions against inviting and really engaging with civil society, as well as the fears of conflicts that could emerge from that. Such fears are not completely irrational, either, as reports on physical and verbal attacks against members of Municipal Councils show. ${ }^{79}$ On the other hand, Gallien and Werenfels observe that since 2018, leading Tunisian politicians often label regular political protest that is against their own interests as attempted putsches, thereby systematically creating a discourse that blurs the lines between democratic and undemocratic action. ${ }^{80}$ This leads to another interesting aspect that was observable in both project examples: the juxtaposition of dialogue and protest.

\section{Citizen dialogue and peaceful demonstration as two constitutional means of exercising influence}

In the project examples described above, citizen dialogue was usually discussed by observers and members of the administration as something in opposition to protest or a "culture of protest": in the first phase of the Water Forum dialogue process in Kairouan particularly, the focus was very much on reducing protests, tensions and conflicts through dialogue. However, it should not be forgotten that it is equally part of the Tunisian people's experience that protest, too, leads to change, such as happened in the 2011 revolution. This is nicely reflected in a survey realised prior to the 2019 presidential and parliamentary elections with a representative sample of the Tunisian population aged eighteen and older. One of the survey questions was "How can ordinary people influence decisions made in our country?" In response to this questions, thirty-three percent of the respondents said they believed that they could influence public decision-making through voting, thirty-three percent said they believed they could influence decisions through protest, and the remaining respondents believed in other forms of influence such as talking directly to officials (six percent), being active in a civil society organisation (five percent), or launching a petition (four percent). Only one percent of the respondents believed that they could influence public de-

78 Conversations with GIZ colleagues accompanying the deconcentration and decentralisation process. GIZ, like other international cooperation partners supporting decentralisation in Tunisia, among other activities facilitates workshops where precisely these definitions of roles and responsibilities are being discussed.

79 Jelassi, Mohamed Khalil, Pouvoir décentralisé et gouvernance locale: Quelle protection pour les élus municipaux?, La Presse, 8.7.2019, https://lapresse.tn/15489/pouvoir-decentralise-et-gouverna nce-locale-quelle-protection-pour-les-elus-municipaux/, accessed on 25 May 2020.

80 Gallien and Werenfels, note 76, p. 6. 
cisions by engaging with Municipal Councils. ${ }^{81}$ Thus, one third of the population according to this survey believes in political change through protest - and not dialogue.

When analysing citizen participation in relation to constitutional provisions, then, it should not be forgotten that protest, at least as long as it remains peaceful, is also a means of democratic participation. According to Article 37 of the Constitution, "The right to assembly and peaceful demonstration is guaranteed." 82 Therefore, it perhaps is not appropriate always to juxtapose protest and dialogue, with protest as dialogue's negative opposition - peaceful protest and dialogue should rather be conceived as two complementary elements of the democratisation process, with protest simply being the form of action less comfortable for the administration to deal with, but a form of action that might be more powerful from the perception of the citizen. ${ }^{83}$

\section{Outlook}

By engaging citizen in water management, and by inviting them to develop ideas for investments in local infrastructure, and to prioritise funding, the Tunisian administration is taking an important step forward in realising provisions of the Tunisian Constitution, even if there is still some uncertainty about the details of how to put these legal provisions into practice. A true willingness to accept some change in existing decision-making procedures and power relations by the representatives of the national government in particular appears to be a condition for the success of such citizen participation. ${ }^{84}$ On the other hand, responsible governance obviously cannot mean that government officials unquestioningly respond to all citizen demands as a result of citizen participation. As the examples have illustrated, taking into account objectives such as ecological sustainability or social and economic distributive justice, the responsible officials in the Tunisian government could not fulfil all wishes of the farmers in Sbikha ${ }^{85}$ or the business people who suggested the fisheries project in NorthWest Tunisia.

81 The International Republican Institute, Center for insights in survey research, Public opinion survey: Residents of Tunisia, January 25-February 11, 2019, https://www.iri.org/sites/default/files/wy siwyg/final_-_012019_iri_tunisia_poll.pdf, accessed on 25 May 2020, p. 36.

82 International IDEA, note 3.

83 Cf. Lierl, note 71, p. 5: "political dissent is rarely expressed through individual participation in public affairs. Political contention is more likely to occur in the form of protests or riots, where individual protesters are protected by the crowd."

84 Cf. Lierl, note 71, p. 6, and Mansuri and Rao, note 70. The latter point out that "community-level trust and reconciliation building is effective only if it is linked to a comparable process at the national level", p. 263.

85 The expectations of some farmers to receive yet more water allocations illustrate the "tragedy of the commons" whereby individuals will strive to increase their own profit without taking into account shared ecological costs, such as overconsumption which ultimately risks destroying everyone's base of living. In such a situation, governments or civil society organisations defending environmental interests have to advocate for and take measures to minimise the ecological risks for the benefit of the community. Cf. Banyan, Margaret E., "Tragedy of the commons", in: Encyclopaedia 
When preparing similar projects around participatory governance, it is therefore recommendable to analyse very well to what extent a government is willing to engage with, or respond to, demands of the population, how transparency towards the population can be guaranteed continuously, and how much willingness there is by those in power to allow for real political change as a consequence of citizen engagement. The more clearly defined it is to what extent citizen can actually influence decision-making at a local or regional level, as opposed to participating for information or consultation only, the easier it would seem to realistically manage expectations on all sides regarding the outcomes of participatory processes. Future application and interpretation of the Tunisian laws on participatory democracy, as well as the creation of the planned Constitutional Court, may also help to clarify further to what extent, and by which mechanisms, the Tunisian legislator intends citizens to be informed, heard, contribute ideas or actively decide in local development planning. 